\title{
ARTICLE
}

\section{Electrochemical properties of zirconium in highly concentrated plutonium nitrate solution}

\author{
Masaumi Nakahara ${ }^{\mathrm{a}^{*}}$, Yuichi Sano a and Hitoshi Abe \\ ${ }^{a}$ Nuclear Fuel Cycle Engineering Laboratories, Japan Atomic Energy Agency, 4-33 Muramatsu, Tokai-mura, Naka-gun, Ibaraki-ken, \\ 319-1194, Japan; ${ }^{b}$ Nuclear Safety Research Center, Japan Atomic Energy Agency, 2-4 Shirakata, Tokai-mura, Naka-gun, \\ Ibaraki-ken, 319-1195, Japan
}

\begin{abstract}
To evaluate the corrosion resistance of a Pu evaporator made of $\mathrm{Zr}$ in the Rokkasho Reprocessing Plant (RRP), the electrochemical properties of $\mathrm{Zr}$ were evaluated in highly concentrated aqueous $\mathrm{Pu}$ nitrate solutions. The open circuit potential of $\mathrm{Zr}$ in the $\mathrm{Pu}$ nitrate solution increased with increasing temperature, and with increasing $\mathrm{HNO}_{3}$ and $\mathrm{Pu}$ concentrations. At the boiling point, $\mathrm{Pu}^{4+}$ and $\mathrm{PuO}_{2}{ }^{2+}$ co-existed in the $\mathrm{Pu}$ nitrate solution. To evaluate the influence of $\mathrm{PuO}_{2}{ }^{2+}$ on the corrosion potential of $\mathrm{Zr}$, the polarization curve of the $\mathrm{Pu}$ nitrate solution containing a high concentration of $\mathrm{PuO}_{2}{ }^{2+}$ with $5 \mathrm{~mol} \mathrm{dm}^{-3} \mathrm{HNO}_{3}$ and $250 \mathrm{~g} \mathrm{dm}^{-3} \mathrm{Pu}$ was measured. The corrosion potential of $\mathrm{Zr}$ stayed in the passive region. The influence of $\mathrm{PuO}_{2}{ }^{2+}$ was not significant in highly concentrated $\mathrm{Pu}$ nitrate solution. These results suggest that $\mathrm{Zr}$ shows high corrosion resistance, even in highly concentrated Pu nitrate solution.
\end{abstract}

Keywords: Rokkasho Reprocessing Plant; evaporator; corrosion resistance; electrochemistry; open circuit potential; polarization curve; zirconium; plutonium

\section{Introduction}

The Rokkasho Reprocessing Plant (RRP) in Aomori, Japan was built for reprocessing irradiated light water reactor fuel, and it is operated with an irradiated nuclear fuel to check the reprocessing equipment. An aqueous separation technique with $\mathrm{HNO}_{3}$ and tri- $n$-butyl phosphate (TBP) $/ n$-dodecane system, called the Plutonium Uranium Redox Extraction (PUREX), has been adopted in RRP. In this process, $\mathrm{U}$ and $\mathrm{Pu}$ are separated from each other as products. Before denitration and conversion, the $\mathrm{Pu}$ nitrate solution is condensed in a $\mathrm{Pu}$ evaporator under the conditions of $50-250 \mathrm{~g} \mathrm{dm}^{-3}$ of $\mathrm{Pu}$ and $3-7 \mathrm{~mol} \mathrm{dm}^{-3}$ of $\mathrm{HNO}_{3}$ at the boiling point [1]. The evaporator is made of $\mathrm{Zr}$ because $\mathrm{Zr}$ has high corrosion resistance to $\mathrm{HNO}_{3}$ solution [2]. The corrosion behavior and electrochemical properties of $\mathrm{Zr}$ have been investigated in $\mathrm{HNO}_{3}$ solution, $\mathrm{Pu}$ nitrate solution, and a dissolver solution of irradiated fast reactor fuels $[3,4]$. It was reported that the corrosion potential of $\mathrm{Zr}$ increased with increasing $\mathrm{Pu}$ concentration in the low $\mathrm{Pu}$ concentration range [4]. Ishijima et al. [5] reported that stress corrosion cracking (SCC) of Zr, with the formation of a black oxide film, occurred when the potentials were nobler than the passivity breakdown potential (around $1.40 \mathrm{~V}$ vs. $\mathrm{Ag} / \mathrm{AgCl}$ in saturated $\mathrm{KCl}$ ) in $9 \mathrm{~mol} \mathrm{dm}^{-3} \mathrm{HNO}_{3}$ at the boiling point in constant load tensile tests. Although Takeda et al. [4] reported the corrosion potential of $\mathrm{Zr}$ in

*Corresponding author. Email: nakahara.masaumi@jaea.go.jp
$3 \mathrm{~mol} \mathrm{dm}^{-3} \mathrm{HNO}_{3}$ and approximately $100 \mathrm{~g} \mathrm{dm}^{-3}$ of $\mathrm{Pu}$ in $\mathrm{Pu}$ nitrate solution at the boiling point, there is little experimental data on the electrochemical properties of $\mathrm{Zr}$ in $\mathrm{Pu}$ nitrate solution containing high concentrations of $\mathrm{HNO}_{3}$ and $\mathrm{Pu}$. In addition, it is important to examine the influence of $\mathrm{PuO}_{2}{ }^{2+}$ on the electrochemical properties of $\mathrm{Zr}$ in the $\mathrm{Pu}$ nitrate solution because $\mathrm{PuO}_{2}{ }^{2+} / \mathrm{Pu}^{4+}$ has high oxidation-reduction potential $[6,7]$ and is very corrosive.

In this study, the electrochemical properties of $\mathrm{Zr}$ in highly concentrated $\mathrm{Pu}$ nitrate solution were investigated to evaluate the corrosion resistance of $\mathrm{Zr}$. These experiments were carried out in a glove box at the Chemical Processing Facility (CPF) in the Japan Atomic Energy Agency (JAEA).

\section{Experimental}

\subsection{Materials}

As the working electrode, an ASTM B551-04 R60702 grade $\mathrm{Zr}$ rolled-plate was used in the experiments. The chemical composition of the $\mathrm{Zr}$ rolled-plate was $\mathrm{H}:<0.0003$ mass $\%, \mathrm{C}: 0.01$ mass $\%, \mathrm{~N}$ : 0.005 mass $\%$, O: 0.13 mass $\%, \mathrm{Fe}+\mathrm{Cr}: 0.07$ mass $\%$, Hf: 1.1 mass \%, and $\mathrm{Zr}+\mathrm{Hf}: \geq 99.2 \operatorname{mass} \%$. The $\mathrm{Zr}$ rolled-plate was cut to $2 \mathrm{~mm}$ diameter $\mathrm{Zr}$ rods and covered with polyether ether ketone (PEEK). The tip of the $\mathrm{Zr}$ electrode with PEEK was cut to $45^{\circ}$ and polished with an abrasive-coated paper. 
Special grade $\mathrm{HNO}_{3}$, TBP, $n$-dodecane, and hydrazine were purchased from Wako Pure Chemical Industries, Ltd. The extraction solvent for $\mathrm{U}$ and $\mathrm{Pu}$ purification, TBP $/ n$-dodecane, was used after a further purification step, but $\mathrm{HNO}_{3}$ and hydrazine were used without further purification.

A Pu nitrate solution was prepared from mixed oxide (MOX) fuel powder derived from irradiated fast reactor fuels. The MOX fuel powder was dissolved in $8 \mathrm{~mol}$ $\mathrm{dm}^{-3} \mathrm{HNO}_{3}$ solution. The MOX fuel dissolver solution was purified with $\mathrm{TBP} / n$-dodecane, and $\mathrm{Pu}$ was separated from U using hydroxylamine nitrate (HAN) purchased from Mitsuwaka Pure Chemicals Research Institute Limited and hydrazine. A small amount of $U$ was detected, but $\mathrm{Pu}$ was essentially separated from $\mathrm{U}$. The valence of $\mathrm{Pu}$ in the $\mathrm{Pu}$ nitrate solution was changed to $\mathrm{Pu}^{4+}$ by bubbling through with $\mathrm{NO}_{x}$ gas.

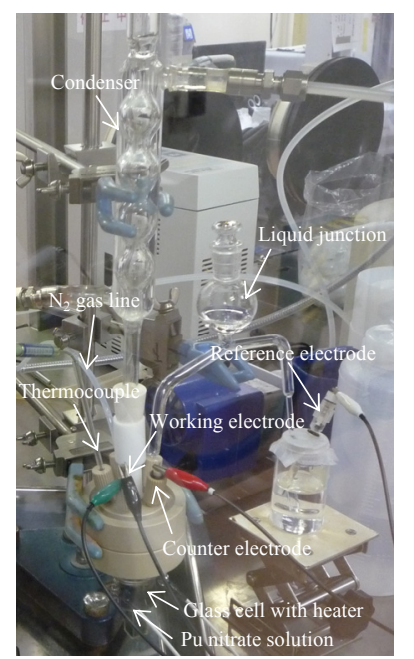

Figure 1. Apparatus setup for electrochemical measurements taken in the glove box.

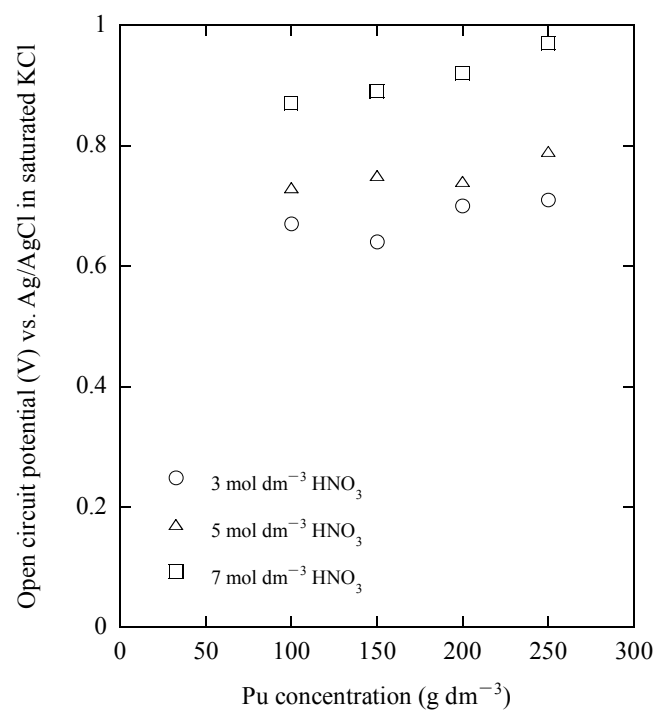

Figure 2. Influence of $\mathrm{HNO}_{3}$ and $\mathrm{Pu}$ concentrations on the open circuit potential of $\mathrm{Zr}$ in $\mathrm{Pu}$ nitrate solution at the boiling point.

\subsection{Procedure}

Figure 1 shows the apparatus setup for the electrochemical measurements taken in the glove box. The apparatus consists of a glass cell with a heater, condenser, working electrode, counter electrode, reference electrode, liquid junction, thermocouple, and thermostat. The $\mathrm{Pu}$ nitrate solution was placed in a glass cell with a heater. The solution temperature was controlled using the thermostat. The PEEK-covered $\mathrm{Zr}$ rod, the working electrode, was immersed in the $\mathrm{Pu}$ nitrate solution. The $\mathrm{Pt}$ electrode was placed in the $\mathrm{Pu}$ nitrate solution and used as the counter electrode. As the liquid junction, a glass tube with a glass filter containing approximately $13.1 \mathrm{~mol} \mathrm{dm}^{-3} \mathrm{HNO}_{3}$ solution was placed in the glass cell and the intermediate cell. The reference electrode, $\mathrm{Ag} / \mathrm{AgCl}$ in saturated $\mathrm{KCl}$, was placed in the intermediate cell.

The $\mathrm{Pu}$ nitrate solution was bubbled with $\mathrm{N}_{2}$ gas for $10 \mathrm{~min}$. The solution was heated to the target temperature in the glass cell. After the target temperature was reached, the open circuit potential was measured $30 \mathrm{~min}$ thereafter. Subsequently, the polarization curve was measured from 0 to $2 \mathrm{~V}$ at a scan rate of $0.003 \mathrm{~V} \mathrm{~s}^{-1}$. The electrochemical measurements of $\mathrm{Zr}$ in the $\mathrm{Pu}$ nitrate solution were controlled using a potentiostat.

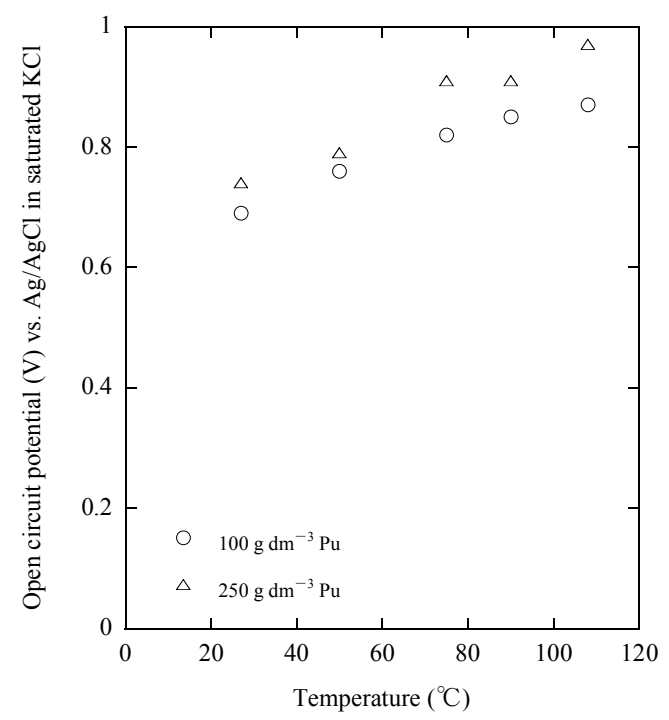

Figure 3. Influence of temperature on the open circuit potential of $\mathrm{Zr}$ in $\mathrm{Pu}$ nitrate solution containing $7 \mathrm{~mol} \mathrm{dm}^{-3}$ $\mathrm{HNO}_{3}$.

\subsection{Analysis}

The acidity of the $\mathrm{Pu}$ nitrate solution was analyzed using titration (COM-1700S, Hiranuma Sangyo Co., Ltd.). The concentrations of $\mathrm{U}$ and $\mathrm{Pu}$ were measured by colorimetry (V-670, JASCO Corporation). An aliquot of the $\mathrm{Pu}$ nitrate solution was diluted with $\mathrm{HNO}_{3}$ before and after the electrochemical measurements, and the valence of $\mathrm{Pu}$ was confirmed using spectroscopy. 


\section{Results and discussion}

\subsection{Influence of temperature, nitric acid, and plutonium concentrations on electrochemical properties of zirconium}

Figure 2 shows the influence of $\mathrm{HNO}_{3}$ and $\mathrm{Pu}$ concentrations on the open circuit potential of $\mathrm{Zr}$ in the $\mathrm{Pu}$ nitrate solution at the boiling point. The open circuit potential of $\mathrm{Zr}$ increased with increasing $\mathrm{HNO}_{3}$ and $\mathrm{Pu}$ concentrations at the boiling point. The open circuit potential of $\mathrm{Zr}$ in relation to $\mathrm{Pu}$ concentration was trended similarly to the results reported by Takeda et al. [4].

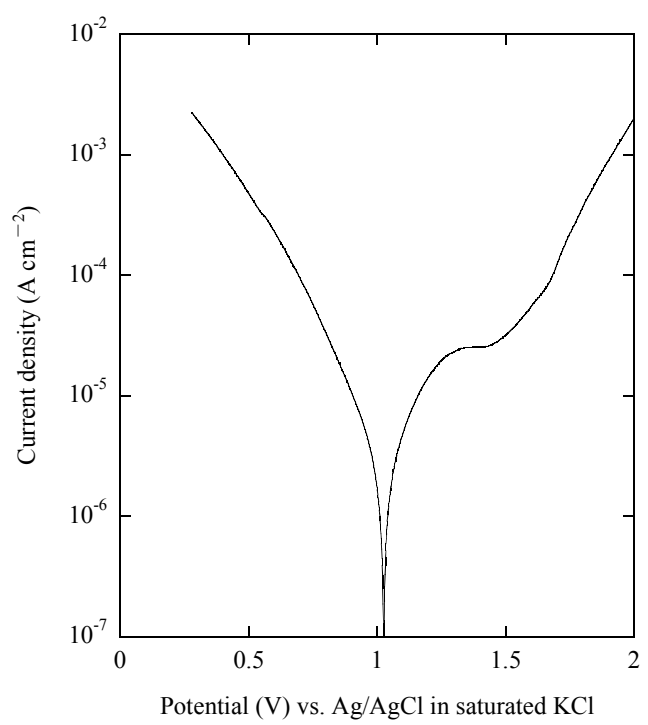

Figure 4. Polarization curve of $\mathrm{Zr}$ in $\mathrm{Pu}$ nitrate solution containing $7 \mathrm{~mol} \mathrm{dm}^{-3} \mathrm{HNO}_{3}$ and $250 \mathrm{~g} \mathrm{dm}^{-3} \mathrm{Pu}$ at the boiling point.

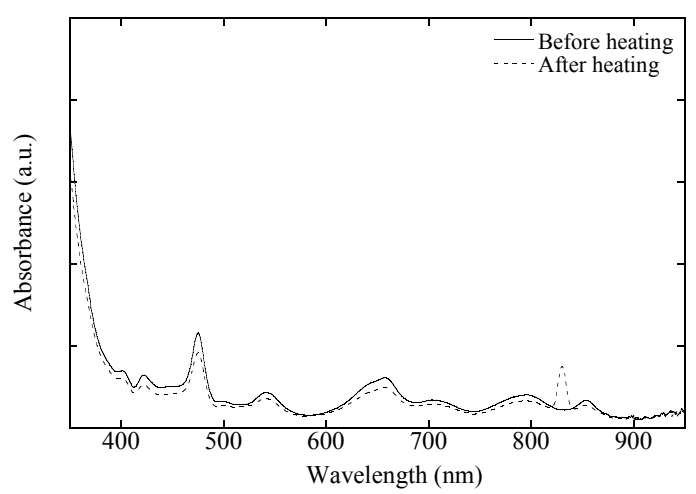

Figure 5. Spectrum of $\mathrm{Pu}$ nitrate solution containing $3 \mathrm{~mol}$ $\mathrm{dm}^{-3} \mathrm{HNO}_{3}$ and $100 \mathrm{~g} \mathrm{dm}^{-3} \mathrm{Pu}$ before heating and after heating.

The influence of temperature on the open circuit potential of $\mathrm{Zr}$ in the $\mathrm{Pu}$ nitrate solution containing 7 mol dm ${ }^{-3} \mathrm{HNO}_{3}$ is plotted in Figure 3. The open circuit potential of $\mathrm{Zr}$ increased with increasing temperature in the $\mathrm{Pu}$ nitrate solution. The open circuit potential of $\mathrm{Zr}$ in the $\mathrm{Pu}$ nitrate solution containing $250 \mathrm{~g} \mathrm{dm}^{-3} \mathrm{Pu}$ was slightly larger than that in the $\mathrm{Pu}$ nitrate solution containing $100 \mathrm{~g} \mathrm{dm}^{-3} \mathrm{Pu}$.

Figure 4 shows the polarization curve of $\mathrm{Zr}$ in the $\mathrm{Pu}$ nitrate solution containing $7 \mathrm{~mol} \mathrm{dm}^{-3} \mathrm{HNO}_{3}$ and $250 \mathrm{~g}$ $\mathrm{dm}^{-3} \mathrm{Pu}$ at the boiling point. The experimental results show that the corrosion potential of $\mathrm{Zr}$ stayed in the passive region.

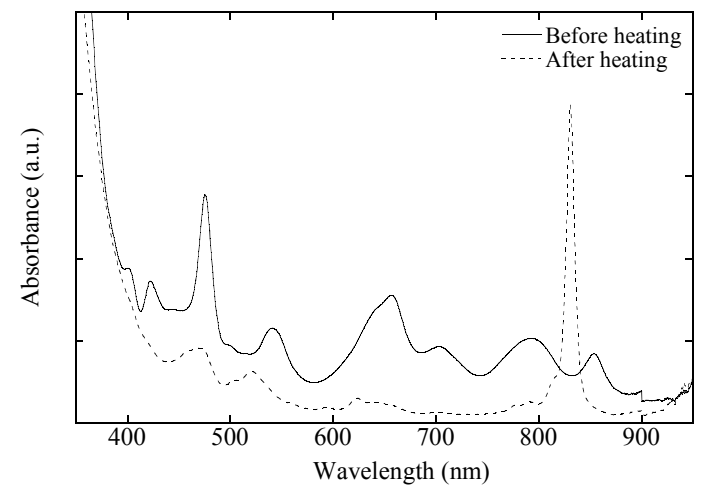

Figure 6. Spectrum of $\mathrm{Pu}$ nitrate solution containing $5 \mathrm{~mol}$ $\mathrm{dm}^{-3} \mathrm{HNO}_{3}$ and $250 \mathrm{~g} \mathrm{dm}^{-3} \mathrm{Pu}$ before heating and after heating for $75 \mathrm{~h}$.

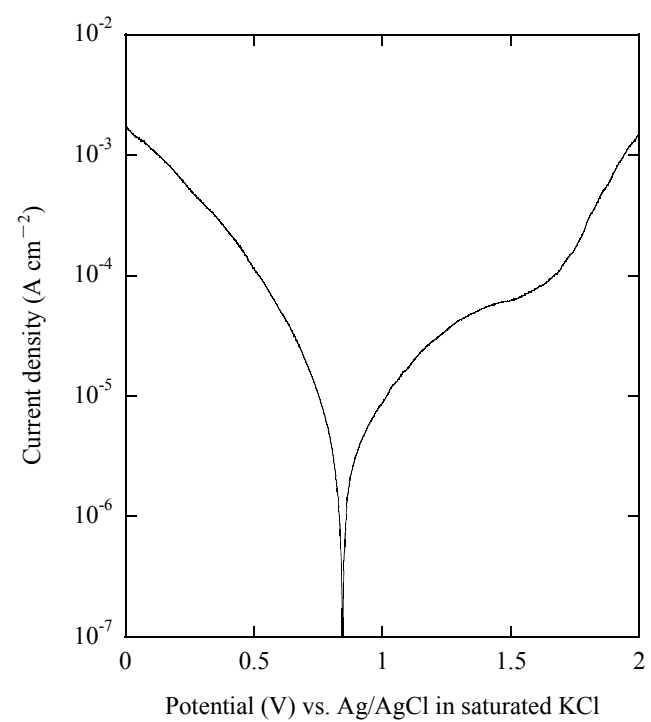

Figure 7. Polarization curve of $\mathrm{Zr}$ in $\mathrm{Pu}$ nitrate solution containing $5 \mathrm{~mol} \mathrm{dm}^{-3} \mathrm{HNO}_{3}$ and $250 \mathrm{~g} \mathrm{dm}^{-3} \mathrm{Pu}$ after heating for $75 \mathrm{~h}$ at the boiling point.

It is known that $\mathrm{Pu}^{4+}$ is oxidized to $\mathrm{PuO}_{2}{ }^{2+}$ by heating aqueous $\mathrm{Pu}$ nitrate as follows [4].

$$
\mathrm{NO}_{3}^{-}+\mathrm{Pu}^{4+}+\mathrm{H}_{2} \mathrm{O} \leftrightarrow \mathrm{HNO}_{2}+\mathrm{PuO}_{2}^{2+}+\mathrm{H}^{+}
$$

The ratio of $\mathrm{PuO}_{2}{ }^{2+}$ increases with decreasing initial $\mathrm{Pu}^{4+}$ and $\mathrm{HNO}_{3}$ concentrations upon heating the solution [8]. In addition, the $\mathrm{PuO}_{2}{ }^{2+}$ ratio increases with increasing solution temperature [8]. Figure 5 shows the spectrum of the $\mathrm{Pu}$ nitrate solution containing $3 \mathrm{~mol} \mathrm{dm}^{-3} \mathrm{HNO}_{3}$ and $100 \mathrm{~g} \mathrm{dm}^{-3} \mathrm{Pu}$ before and after heating to the boiling point. Although the $\mathrm{Pu}^{4+}$ peak was only observed in the $\mathrm{Pu}$ nitrate solution before heating, a $\mathrm{PuO}_{2}{ }^{2+}$ peak was 
observed at $831 \mathrm{~nm}$ after heating. However, the amount of $\mathrm{PuO}_{2}{ }^{2+}$ was small (some dozen $\mathrm{g} \mathrm{dm}^{-3}$ ) in the experimental sample.

It is assumed that the two reduction reactions of $\mathrm{NO}^{3-}$ and $\mathrm{PuO}_{2}{ }^{2+}$ occur as the main cathode reaction [4] and that the reduction of $\mathrm{NO}^{3-}$ proceeds under conditions of high $\mathrm{HNO}_{3}$ concentration. High $\mathrm{Pu}$ concentration and temperature would promote the $\mathrm{Pu}^{4+}$ oxidation reaction, as shown in Eq. (1), and cause an active $\mathrm{PuO}_{2}{ }^{2+}$ reduction reaction on the surface of the electrode. Then, $\mathrm{Pu}^{4+}$ would be oxidized to $\mathrm{PuO}_{2}{ }^{2+}$ with $\mathrm{HNO}_{3}$ again in the bulk. Therefore, activation of cathode reaction can be considered to make the open circuit potential of $\mathrm{Zr}$ high in the Pu nitrate solution, as shown in Figures 2 and 3.

\subsection{Influence of plutonyl ion on electrochemical properties of zirconium}

To investigate the effect of $\mathrm{Pu}$ valence on the corrosion potential of $\mathrm{Zr}$ in $\mathrm{Pu}$ nitrate solution, the polarization curves of $\mathrm{Zr}$ were measured using a $\mathrm{Pu}$ nitrate solution with high concentrations of $\mathrm{PuO}_{2}{ }^{2+}$. The $\mathrm{Pu}$ nitrate solution was adjusted by heating it at the boiling point for $75 \mathrm{~h}$. Figure 6 shows the spectrum of the $\mathrm{Pu}$ nitrate solution containing $5 \mathrm{~mol} \mathrm{dm}{ }^{-3} \mathrm{HNO}_{3}$ and $250 \mathrm{~g} \mathrm{dm}^{-3} \mathrm{Pu}$ before and after heating for $75 \mathrm{~h}$ at the boiling point. After heating, a $\mathrm{PuO}_{2}^{2+}$ peak was observed at $831 \mathrm{~nm}$, and a large amount of $\mathrm{Pu}^{4+}$ was oxidized to $\mathrm{PuO}_{2}{ }^{2+}$ (some hundred $\mathrm{g} \mathrm{dm}^{-3}$ ). Figure 7 shows the polarization curve of $\mathrm{Zr}$ in the $\mathrm{Pu}$ nitrate solution containing $5 \mathrm{~mol} \mathrm{dm}^{-3} \mathrm{HNO}_{3}$ and $250 \mathrm{~g} \mathrm{dm}^{-3} \mathrm{Pu}$ after heating for $75 \mathrm{~h}$ at the boiling point. The corrosion potential of $\mathrm{Zr}$ stayed in the passive region under our experimental conditions, and it was considerably lower than the passivity breakdown potential.

\section{Conclusion}

The open circuit potentials and polarization curves of $\mathrm{Zr}$ in aqueous $\mathrm{Pu}$ nitrate solution were obtained using electrochemical techniques. The open circuit potential of $\mathrm{Zr}$ in $\mathrm{Pu}$ nitrate solution increased with increasing temperature, $\mathrm{HNO}_{3}$ concentration, and $\mathrm{Pu}$ concentration. According to the polarization curve, our research revealed that the corrosion potential of $\mathrm{Zr}$ in a $\mathrm{Pu}$ nitrate solution containing high concentrations of $\mathrm{PuO}_{2}{ }^{2+}$ stayed in the passive region. Therefore, the experimental results indicate that $\mathrm{Zr}$ is corrosion resistant in highly concentrated $\mathrm{Pu}$ nitrate solution.

\section{Acknowledgements}

This work includes experimental results under the auspices of the Nuclear Regulation Authority.

\section{References}

[1] K. Kiuchi, Corrosion problems and countermeasures to corrosion of reprocessing materials used in boiling nitric acid, Nihon-Genshiryoku-Gakkai Shi (J. At. Energy Soc. Jpn.) 31 (1989), pp. 229-238. [in Japanese]

[2] F. Wada, Improvement of reliability in nuclear fuel reprocessing plant, Zairyo-to-Kankyo 48 (1999), pp. 771-775. [in Japanese]

[3] S. Takeda, T. Nagai and T. Koizumi, Corrosion behavior of materials in FBR spent fuel reprocessing solutions, Nihon-Genshiryoku-Gakkai Shi (J. At. Energy Soc. Jpn.) 36 (1994), pp. 146-157. [in Japanese]

[4] S. Takeda, T. Nagai, S. Yasu and T. Koizumi, Corrosion performance of several metals in plutonium nitrate solution, Zairyo-to-Kankyo 44 (1995), pp. 24-29. [in Japanese]

[5] Y. Ishijima, C. Kato, T. Motooka, M. Yamamoto, Y. Kano and T. Ebina, Stress corrosion cracking behavior of zirconium in boiling nitric acid solutions at oxide formation potentials, Mater. Trans. 54 (2013), pp. 1001-1005.

[6] J.D. Moore, R.L. Walser and J.J. Fritch, Purex Technical Manual, RHO-MA-116, Rockwell Hanford Operations, (1980).

[7] R.J. Lemire, J. Fuger, H. Nitsche, P. Potter, M.H. Rand, J. Rydberg, K. Spahiu, J.C. Sullivan, W.J. Ullman, P. Vitorge and H. Wanner, Chemical Thermodynamics of Neptunium and Plutonium, OECD Nuclear Energy Agency, Elsevier, North Holland, (2001), pp. 301-316, ISBN 0-444-50379-X.

[8] S.A. Glazyrin, P.Yu. Rodchenko and L.P. Sokhina, Oxidation of plutonium(IV) on heat treatment of concentrated nitrate solutions, Radiokhimiya 31 (1989), pp. 48-52. 